\title{
Effect of Q\&P parameters on microstructure development and mechanical behaviour of Q\&P steels
}

\author{
Irene De Diego-Calderón ${ }^{\mathrm{a}, \bowtie}$, Dorien De Knijf ${ }^{\mathrm{b}}$, Jon M. Molina-Aldareguia ${ }^{\mathrm{a}}$, \\ Ilchat Sabirov ${ }^{\mathrm{a}}$, Cecilia Föjer ${ }^{\mathrm{c}}$, Roumen Petrov ${ }^{\mathrm{b}, \mathrm{d}}$ \\ ${ }^{a}$ IMDEA Materials Institute, Calle Eric Kandel 2, Getafe, 28906, Madrid, Spain \\ ${ }^{b}$ Department of Materials Science and Engineering, Gent University, Technologiepark 903, B-9052 Zwijnaarde (Gent), Belgium \\ ${ }^{\mathrm{c}}$ Arcelor Mittal Global R\&D Gent, Pres. J. F. Kennedylaan 3, B-9060 Zelzate, Belgium \\ ${ }^{\mathrm{d}}$ Department of Materials Science and Engineering, Delft University of Technology, 2628 CD Delft, The Netherlands \\ corresponding author: irenedediego.calderon@imdea.org
}

Submitted: 18 November 2014; Accepted: 21 December 2014; Available On-line: 2 March 2015

\begin{abstract}
Steel with a nominal composition of $0.25 \mathrm{C}-1.5 \mathrm{Si}-3 \mathrm{Mn}-0.023 \mathrm{Al}$ (mass \%) was subjected to Quenching and Partitioning (Q\&P) with varying parameters (quenching temperature, partitioning temperature and partitioning time) resulting in formation of multi-phase microstructure, which was thoroughly studied using X-ray (XRD) and Electron Backscatter Diffraction (EBSD). Mechanical properties of the Q\&P steel were measured by tensile tests. Plastic deformation of Q\&P steel at micro-scale was investigated by in situ tensile testing and digital image correlation analysis. The effect of Q\&P parameters on the microstructure (phase composition, size and volume fraction of micro constituents, texture and carbon content in retained austenite) is discussed. After analyzing the mechanical properties, plastic deformation at the micro-scale and the microstructure, it is shown that the strain partitioning between phases strongly depends on the microstructure of the Q\&P steel, which, in turn, can be tuned via manipulation with Q\&P parameters.
\end{abstract}

KEYWORDS: Deformation; Mechanical properties; Phase transformation; Quenching and partitioning; Retained austenite; Steels

Citation / Cómo citar este artículo: De Diego-Calderón, I., De Knijf, D., Molina-Aldareguia, J.M., Sabirov, I., Föjer, C., Petrov, R. (2015) "Effect of Q\&P parameters on microstructure development and mechanical behaviour of Q\&P steels". Rev. Metal. 51(1): e035. doi: http://dx.doi.org/10.3989/revmetalm.035.

RESUMEN: Efecto de los parámetros de procesado en el desarrollo microestructural y en las propiedades mecánicas en aceros $Q \& P$. Con el objetivo de evaluar el efecto de los parámetros de procesado en un acero con una composición nominal de $0,25 \mathrm{C}-1,5 \mathrm{Si}-3 \mathrm{Mn}-0,023 \mathrm{Al}$ (\% masa), éste ha sido sometido a un tratamiento térmico denominado "Quenching and Partitioning" (Q\&P), en el que se han variado la temperatura de "quenching", la temperatura de "partitioning" y el tiempo de "partitioning". Como resultado se ha obtenido una microestructura multifásica, la cual ha sido analizada en detalle utilizando difracción de rayos-X (XRD) y de electrones retrodispersados (EBSD). Asimismo, se han medido las propiedades mecánicas de los aceros Q\&P mediante ensayos de tracción. La deformación plástica de los aceros Q\&P a nivel micrométrico ha sido estudiada mediante ensayos "in situ" en el microscopio electrónico de barrido y la posterior aplicación de la técnica de correlación digital de imágenes. Se ha determinado el efecto de los parámetros de procesado en la microestructura (composición de fases, tamaño y fracción en volumen de los distintos micro constituyentes, textura y contenido en carbono en la austenita retenida). Una vez se han relacionado las propiedades mecánicas, la deformación plástica a nivel micrométrico y la microestructura, se concluye que la partición de la deformación entre fases depende en gran medida de la propia microestructura del acero Q\&P, que a su vez puede ser ajustada a través de la manipulación de los parámetros de procesado.

PALABRAS CLAVE: Aceros; Austenita retenida; Deformación; Propiedades mecánicas; "Quenching and partinioning"; Transformación de fase

Copyright: (C) 2015 CSIC. This is an open-access article distributed under the terms of the Creative Commons Attribution-Non Commercial (by-nc) Spain 3.0 License. 


\section{INTRODUCTION}

The current trends in the automotive industry have been mainly focused on increasing the crashworthiness properties of vehicles, while decreasing fuel consumption and gas emissions at the same time. For this purpose, the steel industry is continuously presenting innovative solutions to the automotive industry, since this material has the ability to adapt to the changing requirements. In particular, the past few decades have witnessed a significant research effort directed towards the development of Advanced High-Strength Steel (AHSS) grades, as they provide an opportunity for the development of cost-effective and light-weight parts with improved safety and optimized environmental performance for automotive applications (Bhadeshia, 1999; De Moor et al., 2010; Caballero et al., 2013; Rodríguez et al., 2014). These research strategies are based on the development of microstructures consisting of ultrafine microconstituents formed in non-equilibrium conditions, such as martensite or bainite, in combination with Retained Austenite (RA) (Santofimia et al., 2008; Caballero et al., 2009; Garcia-Mateo et al., 2012). Harder microconstituents contribute to a simultaneous increase of strength and toughness whereas RA provides the improvement of strength and ductility through the Transformation Induced Plasticity (TRIP) effect (Speer et al., 2005; Santofimia et al., 2008). The strain induced transformation to martensite provides an additional deformation and strainhardening mechanism, thereby suppressing strain localization and enhancing formability (Speer and Matlock, 2002; Gutiérrez et al., 2013).

Speer et al., proposed in 2003 a novel processing route, "Quenching and Partitioning" (Q\&P) (Speer et al., 2003). Q\&P appears promising as a further improvement of mechanical properties can be attained via intelligent microstructural design (De Diego-Calderón et al., 2014; De Knijf et al., 2014a). The Q\&P process consists of a multi-step thermal processing route: first, after heating in order to obtain a fully austenitic or intercritical microstructure, the steel is quenched to a suitable pre-determined temperature (QT) below the martensite start (Ms) but above the martensite finish (Mf) temperatures to form a pre-defined amount of martensite; then, the steel is either held at this quenching temperature or brought to a higher Partitioning Temperature (PT), where the untransformed austenite is carbonenriched through carbon depletion of the supersaturated martensite (Edmonds et al., 2006; De Moor et al., 2011). In this way, a complex microstructure formed by metastable RA and martensite is obtained after final quenching to room temperature. Although there are already works on characterization of the steel microstructure after Q\&P (Santofimia et al., 2008; De Diego-Calderón et al.,
2014; De Knijf et al., 2014a; Tan et al., 2014a; Tan et al., 2014b), there is still a lack of knowledge about the strain distribution between the microstructural constituents in Q\&P structures during loading in the plastic range. Low carbon TRIP steel compositions have been used to successfully generate martensitic microstructures with substantial RA levels through Q\&P processing (Speer et al., 2014). Addition of elements, such as Si, retards the formation of carbides and gives rise to the carbon enrichment of austenite (Santofimia et al., 2008; Paravicini Bagliani et al., 2013). Moreover, increased manganese levels have been shown to be effective at reporting significant austenite fractions with improved tensile properties in Q\&P steels (De Moor et al., 2011; Speer et al., 2014). Mechanical property studies indicate that Q\&P shows significant potential to generate novel property combinations that would otherwise be difficult in low alloy compositions (Speer et al., 2014). Fundamental understanding of the property - microstructure relationships in this type of steels has not been achieved, which is required for further improvement of the properties via intelligent microstructural design. Therefore, the objective of the present work is to relate the mechanical behaviour of a Q\&P steel with its microstructure (phase composition, size of microconstituents, carbon content in RA, etc.) and Q\&P parameters.

\section{EXPERIMENTAL}

\subsection{Materials and processing}

Steel with a nominal composition of $0.25 \mathrm{C}-1.5 \mathrm{Si}-$ $3 \mathrm{Mn}-0.023 \mathrm{Al}$ (mass \%), produced in a laboratory vacuum induction furnace was studied. After casting, the steel slabs were hot rolled to a final thickness of $2.5 \mathrm{~mm}$, accelerated cooled by water jets to $600^{\circ} \mathrm{C}$ and transferred to a furnace for coiling simulations at $560^{\circ} \mathrm{C}$. The hot rolled plates were pickled and cold rolled to a thickness of $1 \mathrm{~mm}$ imposing a total reduction in thickness of $60 \%$. The obtained strips were cut perpendicular to the rolling direction and subsequently subjected to Q\&P heat treatment cycles in the thermo-mechanical simulator Gleeble ${ }^{\mathrm{TM}}$ 3500. The specimens were heated to $850^{\circ} \mathrm{C}$ for full austenitization, quenched to varying Quenching Temperatures (QT) at quenching rate of $20^{\circ} \mathrm{C} \mathrm{s}^{-1}$ in order to obtain microstructures consisting of martensite and austenite. Then the samples were reheated with a heating rate of $10{ }^{\circ} \mathrm{C} \mathrm{s}^{-1}$ and kept isothermally at different Partitioning Temperatures (PT) for varying Partitioning times $(\mathrm{Pt})$. During this stage, carbon diffusion occurs from supersaturated martensite into untransformed austenite that stabilizes austenite during further final quenching to room temperature with a rate of $20^{\circ} \mathrm{C} \mathrm{s}^{-1}$. Data on the Q\&P parameters applied to the studied steel grade are presented in Table 1. In the following, the 
TABLE 1. Q\&P processing parameters applied to the studied steel grade

\begin{tabular}{lccc}
\hline Specimen & $\begin{array}{c}\text { Quenching Temperature } \\
(\mathbf{Q T})\left({ }^{\circ} \mathbf{C}\right)\end{array}$ & $\begin{array}{c}\text { Partitioning Temperature } \\
(\mathbf{P T})\left({ }^{\circ} \mathbf{C}\right)\end{array}$ & $\begin{array}{c}\text { Partitioning time } \\
(\mathbf{P t})(\mathbf{s})\end{array}$ \\
\hline $224-350-500$ & 224 & 350 & 500 \\
$244-300-500$ & 244 & 300 & 500 \\
$244-350-500$ & 244 & 350 & 500 \\
$244-400-100$ & 244 & 400 & 100 \\
$244-400-500$ & 244 & 400 & 500 \\
$244-400-1000$ & 244 & 400 & 1000 \\
$264-350-500$ & 264 & 350 & 500 \\
\hline
\end{tabular}

investigated specimens are referred to by numbers showing the applied QT, followed by their PT and $\mathrm{Pt}$, as indicated in Table 1.

\subsection{Microstructural characterization}

Specimens for microstructural characterization were ground and polished with a final polishing step of $1 \mu \mathrm{m}$ diamond paste using classical metallographic techniques. For scanning electron microscopy characterization, specimens were etched with 2 vol. $\%$ $\mathrm{HNO}_{3}$ in ethanol (nital 2\%) solution for 5 seconds at room temperature $\left(22^{\circ} \mathrm{C}\right)$. Examination of the microstructure was performed using a Scanning Electron Microscope (SEM) EVO MA15 operating at an accelerating voltage of $20 \mathrm{kV}$. Specimens for EBSD analysis were prepared using standard metallographic technique with final polishing with OP-U for 20 minutes. Orientation Imaging Microscopy (OIM) studies were performed using a FEI Quanta ${ }^{\mathrm{TM}}$ 450 FEG-SEM equipped with a Hikari detector controlled by the EDAX-TSL OIM-Data Collection (version $6.2^{\circledR}$ ) software. The data were acquired at an accelerating voltage of $20 \mathrm{kV}$, a working distance of $16 \mathrm{~mm}$, a tilt angle of $70^{\circ}$ and a step size of $40 \mathrm{~nm}$. The orientation data were post-processed and analysed with TSL-OIM Analysis $6.2^{\mathcal{O}}$ software. The post-processing procedure included appropriate "clean-up" steps and after that removing of the point with Confidence Index (CI) lower than 0.1 as dubious.

The volume fractions of RA and its average carbon content at room temperature were measured by XRD experiments performed on a Siemens Kristalloflex D5000 diffractometer equipped with a Mo-K $\mathrm{K}_{\alpha}$ source operating at $40 \mathrm{kV}$ and $40 \mathrm{~mA}$. A $2 \Theta$-range of $25^{\circ}$ to $45^{\circ}$ was scanned using a step size of $0.01^{\circ}$, dwell-time of 2 seconds and a rotation speed of $15 \mathrm{rpm}$. The data were post-processed by subtracting the background radiation and $K \alpha_{2}$ influence. The volume fractions of RA were determined by the Cullity formula (Cullity, 1978), and the austenite lattice parameter $a_{\gamma}$ was estimated from the extrapolation function of the lattice parameter vs. $\cos ^{2}(\theta) / \sin (\theta)$ of the (200), (220) and (311) austenite peaks. The carbon concentration $\mathrm{X}_{\mathrm{C}}$ was obtained according to the procedure proposed in van Dijk et al. (2005), where the link between the lattice parameter of the retained austenite was presented as:

$a_{\gamma}=0.3556+0.00453 \mathrm{X}_{\mathrm{C}}+0.000095 \mathrm{X}_{\mathrm{Mn}}+0.00056 \mathrm{X}_{\mathrm{Al}}$

where $\mathrm{a}_{\gamma}$ is the austenite lattice parameter in $\mathrm{nm}$ and $\mathrm{X}_{\mathrm{C}}, \mathrm{X}_{\mathrm{Mn}}$ and $\mathrm{X}_{\mathrm{Al}}$ are the concentrations of carbon, manganese and aluminium in austenite in wt.\%. Volume fractions of Tempered Martensite (TM) and Untempered Martensite (UM) were estimated from the OIM images using the free Image J software (Schneider et al., 2012).

\subsection{In situ tensile tests and digital image correlation analysis}

Miniature tensile specimens having a gauge length of $4 \mathrm{~mm}$, a gauge width of $1 \mathrm{~mm}$ and a thickness of $1 \mathrm{~mm}$ were machined from the Q\&P processed strips. In situ tensile tests were carried out in the SEM EVO MA15 operating at an accelerating voltage of $20 \mathrm{kV}$. Tensile specimens were loaded at room temperature using a Kammrath\&Weiss tensile/compression module embedded in the SEM chamber. Tensile specimens were deformed to failure with the constant cross-head speed corresponding to the initial strain rate of $10^{-3} \mathrm{~s}^{-1}$. Tensile deformation was stopped periodically, the tensile specimens were unloaded and secondary electron micrographs with $1024 \times 768$ pixel resolution were taken from the central area of the miniature tensile specimens after each deformation step. The cross-head displacement steps were $100 \mu \mathrm{m}$ corresponding to a global strain of $2.5 \%$. The analyzed areas had dimensions of $20 \times 25 \mu \mathrm{m}^{2}$.

The Digital Image Correlation (DIC) technique was utilized to determine local in-plane plastic strain distribution after tensile deformation of the Q\&P steels. SEM images of the specimens before and after each deformation step were uploaded into the Vic-2D 2009 Digital Image Correlation software for full-field strain analysis and generation of plastic deformation maps. 


\section{RESULTS AND DISCUSSION}

\subsection{Effect of $Q \& P$ parameters on microstructure and mechanical properties}

OIM phase maps with bcc in blue and fcc in yellow superimposed with the image quality maps of the studied samples are shown in Fig. 1. After the Q\&P treatment, irregular-shaped blocks of TM constitute the major phase of the microstructure, whereas the others (i.e. UM and RA) are dispersed in the matrix. The size of the microconstituents (TM and RA) is provided in Table 2. The average size of TM for all specimens is in the same range. Nevertheless, the Q\&P parameters have a slight effect on the RA average grain size. Due to a less perfect bcc lattice, UM regions formed during the last quench to room temperature can be identified
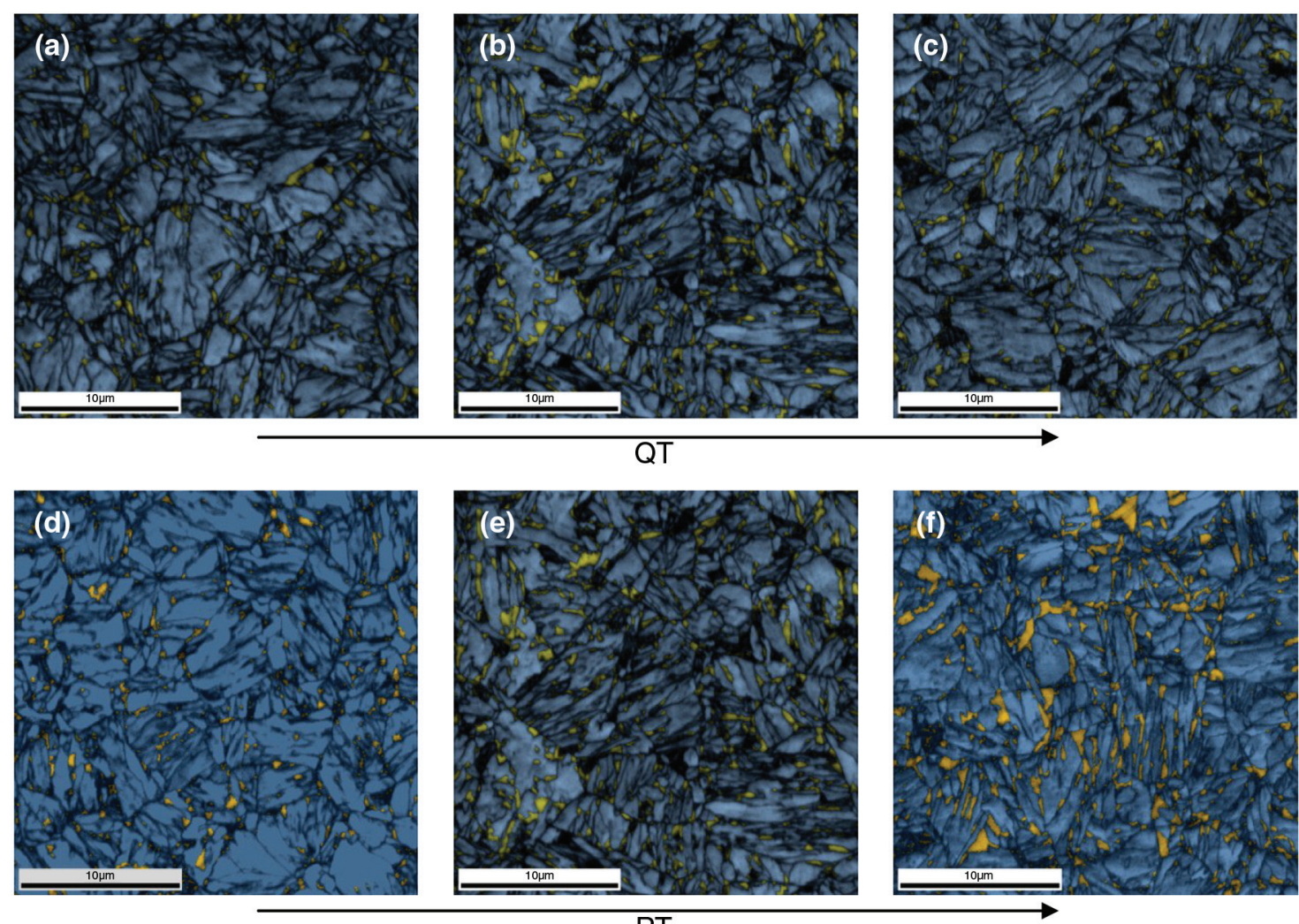

PT
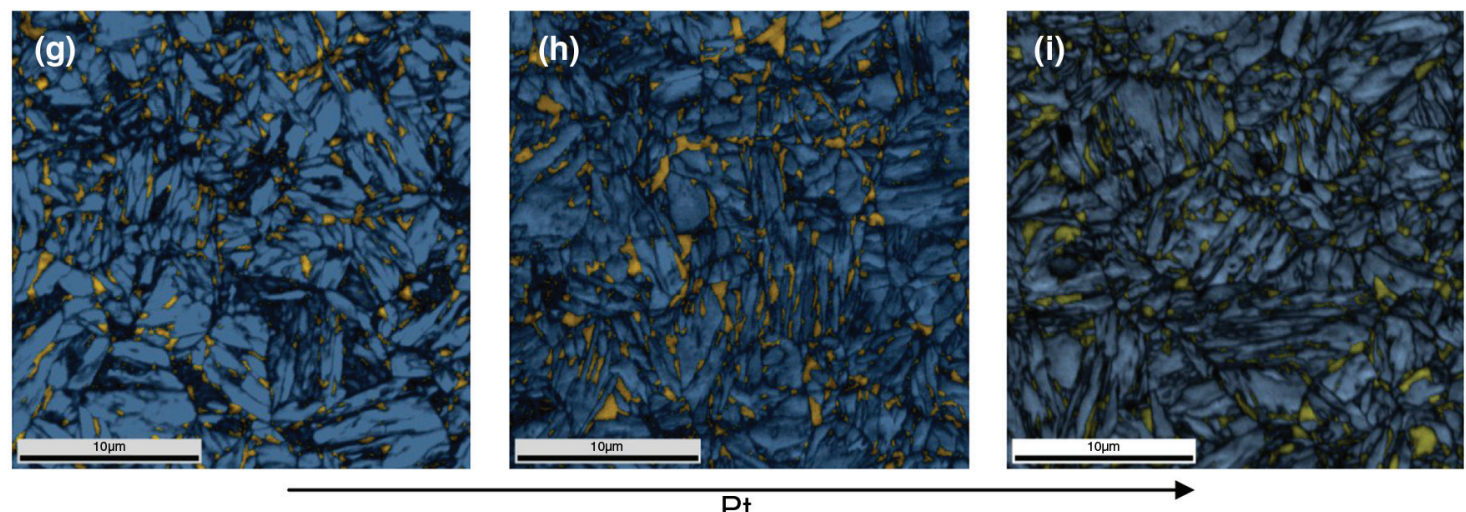

Figure 1. OIM pictures of: (a) the sample quenched at $224^{\circ} \mathrm{C}(224-350-500)$, (b) the sample quenched at $244{ }^{\circ} \mathrm{C}(244-350-500)$ and (c) the sample quenched at $264^{\circ} \mathrm{C}$ for $500 \mathrm{~s}(264-350-500)$; all of them were partitioned at $350{ }^{\circ} \mathrm{C}$ for $500 \mathrm{~s}$. (d) The sample partitioned at $300{ }^{\circ} \mathrm{C}$ for $500 \mathrm{~s}(244-300-500)$, (e) the sample partitioned at $350{ }^{\circ} \mathrm{C}$ for $500 \mathrm{~s}(244-350-500)$ and (f) the sample partitioned at $400{ }^{\circ} \mathrm{C}$ for $500 \mathrm{~s}(244-400-500)$; all of them were quenched at $244^{\circ} \mathrm{C}$. (g) The sample partitioned at $400{ }^{\circ} \mathrm{C}$ for $100 \mathrm{~s}(244-400-100)$, (h) the sample partitioned at $400{ }^{\circ} \mathrm{C}$ for $500 \mathrm{~s}(244-400-500)$ and (i) the sample partitioned at $400{ }^{\circ} \mathrm{C}$ for $1000 \mathrm{~s}(244-400-1000)$; all of them were quenched at $244^{\circ} \mathrm{C}$. Austenite is in yellow, tempered martensite in blue and untempered martensite in dark blue. 
TABLE 2. Average grain size (equivalent circle diameter) for the different microconstituents of the Q\&P steel

\begin{tabular}{lcccccc}
\hline & \multicolumn{2}{c}{$\begin{array}{c}\text { Tempered Martensite } \\
\text { (TM) }\end{array}$} & & \multicolumn{2}{c}{$\begin{array}{c}\text { Retained Austenite } \\
\text { (RA) }\end{array}$} \\
\cline { 2 - 3 } \cline { 6 - 7 } \cline { 5 - 6 } Specimen & \multicolumn{2}{c}{$(\boldsymbol{\mu m})$} & & & \multicolumn{2}{c}{$(\boldsymbol{\mu m})$} \\
\hline $224-350-500$ & 2.7 & \pm 0.3 & & 0.5 & \pm 0.1 \\
$244-300-500$ & 2.3 & \pm 0.1 & & 0.4 & \pm 0.1 \\
$244-350-500$ & 2.2 & \pm 0.4 & & 0.6 & \pm 0.1 \\
$244-400-100$ & 2.2 & \pm 0.2 & & 0.5 & \pm 0.1 \\
$244-400-500$ & 2.2 & \pm 0.3 & & 0.7 & \pm 0.1 \\
$244-400-1000$ & 2.4 & \pm 0.1 & & 0.7 & \pm 0.2 \\
$264-350-500$ & 2.5 & \pm 0.3 & & 0.5 & \pm 0.1 \\
\hline
\end{tabular}

as the darkest ones and can be found in the vicinity of the yellow RA grains. The size of the UM can be roughly estimated but could not be accurately measured from the available OIM maps, since lattice distortion leads to a low pattern quality and indexation of the UM zones in the OIM scans. Various RA morphologies are present in the microstructure (Fig. 1): film-like RA, lamellar RA and blocky RA. A thorough analysis of the available OIM micrographs shows the growth of interlath RA from filmlike to a blocky type as a function of partitioning parameters. Although the spatial resolution of the EBSD technique is reasonably high (step size is $40 \mathrm{~nm}$ ), the smallest austenite laths formed between the martensite plates, as observed with TEM, have sizes in the range of 20-100 nm (Xiong et al., 2013; De Knijf et al., 2014a). The laths can therefore not be resolved by EBSD but are detectable with XRD. Table 3 lists the measurements of volume fraction and carbon content of RA, as well as the volume fraction of TM and UM which were determined by X-ray diffraction combined with EBSD analysis. Finally, Table 4 summarizes the mechanical properties measured on miniature samples of the studied

TABLE 3. Volume fraction and carbon content (wt.\%) of retained austenite and volume fraction of untempered and tempered martensite in the studied steel

\begin{tabular}{|c|c|c|c|c|}
\hline \multirow[b]{2}{*}{ Specimen } & \multicolumn{2}{|c|}{$\begin{array}{c}\text { Retained } \\
\text { Austenite } \\
\text { (RA) }\end{array}$} & \multirow{2}{*}{$\begin{array}{c}\begin{array}{c}\text { Untempered } \\
\text { Martensite } \\
\text { (UM) }\end{array} \\
(\%)\end{array}$} & \multirow{2}{*}{$\begin{array}{c}\text { Tempered } \\
\text { Martensite } \\
\text { (TM) }\end{array}$} \\
\hline & $(\%)$ & $\% \mathrm{C}$ (wt.) & & \\
\hline $224-350-500$ & 14.2 & 0.91 & 13.8 & 72.0 \\
\hline 244-300-500 & 14.7 & 1.05 & 17.7 & 67.6 \\
\hline 244-350-500 & 14.4 & 0.99 & 14.1 & 71.5 \\
\hline 244-400-100 & 18.3 & 0.84 & 9.9 & 71.8 \\
\hline 244-400-500 & 17.9 & 1.03 & 12.2 & 69.9 \\
\hline $244-400-1000$ & 20.2 & 1.01 & 10.5 & 69.3 \\
\hline $264-350-500$ & 13.5 & 1.11 & 15.8 & 70.7 \\
\hline
\end{tabular}

TABLE 4. Mechanical properties measured on miniature samples of the studied steel grade $\left(0.2 \%\right.$ proof stress $\sigma_{0.2}$, ultimate tensile strength $\sigma_{U T S}$, uniform elongation $\varepsilon_{u}$, elongation to failure $\varepsilon_{f}$, strain hardening exponent $n$ )

\begin{tabular}{|c|c|c|c|c|c|}
\hline Specimen & $\frac{\sigma_{0.2}}{(\mathrm{MPa})}$ & $\frac{\sigma_{U T S}}{(\mathrm{MPa})}$ & $\frac{\varepsilon_{u}}{(\%)}$ & $\begin{array}{c}\varepsilon_{f} \\
(\%)\end{array}$ & $n$ \\
\hline $224-350-500$ & 900 & 1357 & 10 & 22 & 0.19 \\
\hline $244-300-500$ & 721 & 1419 & 10 & 21 & 0.25 \\
\hline $244-350-500$ & 803 & 1471 & 11 & 21 & 0.26 \\
\hline 244-400-100 & 621 & 1462 & 17 & 26 & 0.24 \\
\hline $244-400-500$ & 821 & 1267 & 16 & 28 & 0.19 \\
\hline $244-400-1000$ & 681 & 1275 & 16 & 29 & 0.20 \\
\hline $264-350-500$ & 761 & 1354 & 13 & 24 & 0.24 \\
\hline
\end{tabular}

steel grade. Below, the effect of each Q\&P parameter (QT, PT, Pt) on microstructure and mechanical properties is analysed.

\subsubsection{Influence of $Q T$}

The EBSD phase maps of the three samples quenched at different temperatures (224-350-500, 244-350-500 and 264-350-500) are shown in Fig. 1 (a,b and c). By comparing these samples it can be observed that the QT affects neither the TM, nor the RA average size (Table 2). In addition, it can be seen that the average volume fraction of RA ranges from $13.5 \%$ to $14.4 \%$, whereas its carbon content ranges from 0.91 to $1.11 \mathrm{wt} . \%$ and appears to increase with increasing QT (Table 3).

Various RA morphologies are present in the microstructure. In the 244-350-500 sample mostly blocky RA can be found, whereas in the 224-350-500 and 246-350-500 samples the prevalent type is the interlath lamellar one, but some blocky RA is also observed. As it was already reported in literature (Tirumalasetty et al., 2012; De Knijf et al., 2014a), localized EBSD scans yield significantly lower RA fractions, being $5.0 \%, 8.8 \%$ and $5.9 \%$ for the 224-350-500, 244-350-500 and 264-350-500 samples, respectively. Therefore, the fraction of smallest austenite laths (film-like type), which are not detected by EBSD, is higher in the samples quenched at $224^{\circ} \mathrm{C}$ and $264^{\circ} \mathrm{C}$, respectively. The volume fraction of UM is $13.8 \%, 14.1 \%$ and $15.8 \%$ for the samples quenched at $224{ }^{\circ} \mathrm{C}, 244{ }^{\circ} \mathrm{C}$ and $264^{\circ} \mathrm{C}$ respectively. Finally, the volume fraction of TM tends to slightly decrease with the QT: values of $72.0 \%, 71.5 \%$ and $70.7 \%$ were obtained for the samples quenched at $224^{\circ} \mathrm{C}, 244^{\circ} \mathrm{C}$ and $264^{\circ} \mathrm{C}$, respectively.

A hypothetical explanation for these observations can be offered: the fraction of martensite that undergoes carbon partitioning to the neighbouring austenite during the partitioning step is determined to a large extent by the QT. The stabilized RA fraction is less dependent on higher QTs due to kinetic 
effects related to lower carbon diffusion in austenite creating pile-ups close to the grain boundaries resulting in local stabilization of austenite. Thus, a QT closely below the Ms temperature results in a small fraction of martensite, so the carbon available for partitioning might not be sufficient for the stabilization of the austenite. This indeed leads to a high fraction of relatively unstable austenite that transforms to martensite in the final quench. On the other hand, lower QT results in the formation of a higher fraction of martensite in the first quench. Therefore, a higher fraction of austenite is consumed during the initial quench, that will not be available for carbon enrichment during the partitioning step (Speer et al., 2005; Santofimia et al., 2011a).

Figure $2 \mathrm{a}$ shows the engineering stress - engineering strain curves from tensile testing of the 224-350-500, 244-350-500 and 264-350-500 samples. In addition, their mechanical properties are summarized in Table 4. In TRIP steels, it is known that not only the volume fraction of RA, but also its transformation stability plays an important role in determining the global mechanical properties (Furnemont et al., 2002; Ahn et al., 2010; Xiong et al., 2013; Xie et al., 2014). In fact, similar behaviour has also been reported (De Diego-Calderón et al., 2014; De Knijf et al., 2014a) in Q\&P steels. It has also been already shown in literature that transformation stability of austenite is affected by many factors, among others the carbon concentration in the austenite grains (van Dijk et al., 2005; Blondé et al., 2014), its grain size (Jimenez-Melero et al., 2007), the constraining effect of the surrounding phases (Jacques et al., 2001a) and its morphology (Xiong et al., 2013). In our case, carbon content, grain size and the surrounding phases of RA (fractions of TM and UM) are very similar for the 224-350-500, 244-350-500 and 264-350-500 samples. Therefore, RA morphology should be the main factor explaining the difference in mechanical properties for the three studied conditions.

RA presenting film-like or interlath lamellar morphologies have better transformation stability compared with a blocky type, which tends to transform to martensite under a small strain and contributes little to the TRIP effect (Speer et al., 2005; De Moor et al., 2008; Xiong et al., 2013; Ding et al., 2014), as it is 'consumed' during the early stage of plastic deformation (De Diego-Calderón et al., 2014). Thus, in the 244-350-500 sample containing mostly blocky RA, it suddenly transforms after yielding to martensite via TRIP effect (Speer et al., 2005; De Moor et al., 2008), whereas this might be not the case for interlath-lamellar RA or film-like RA. Therefore, after yielding the amount of UM, which contributes to the material's strength, is increased. This martensite will be different to that previously formed as it will normally be expected to inherit a higher carbon concentration (Edmonds et al., 2006; Santofimia
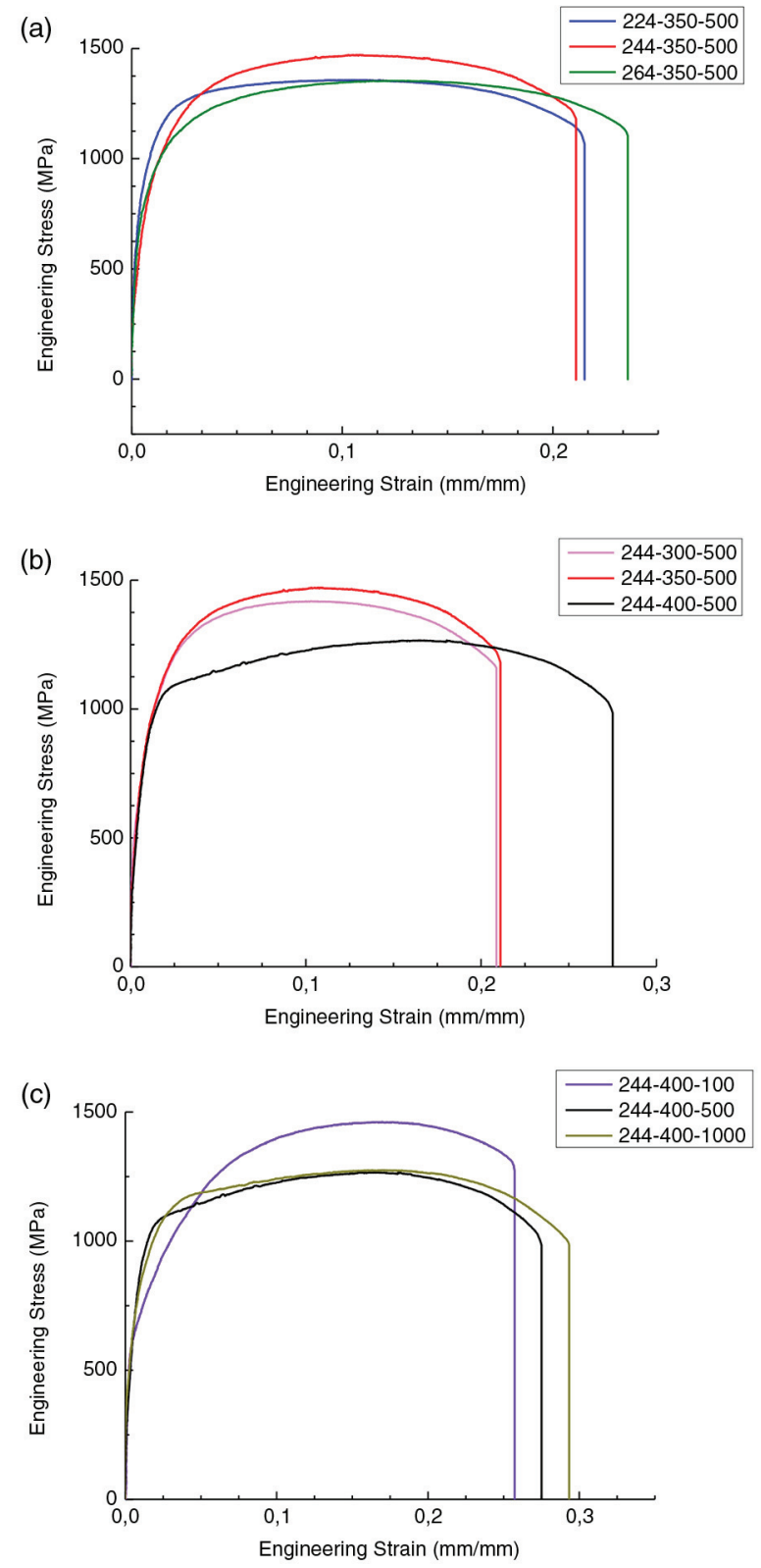

FIGURE 2. Engineering stress - engineering strain curves from tensile testing of the: (a) 224-350-500, 244-350-500 and 264350-500 samples; (b) 244-300-500, 244-350-500 and 244-400-500 samples; (c) 244-400-100, 244-400-500 and 244-400-1000 samples.

et al., 2011b). For this reason, the $\sigma_{U T S}$ value for the 244-350-500 sample might be the highest one.

Slightly inferior $0.2 \%$ proof stress $\left(\sigma_{0.2}\right)$ values are found for the 244-350-500 and the 264-350-500 samples. Yielding in these two steel grades should start earlier, considering that the blocky RA is deformed plastically before its transformation via TRIP effect. Besides, this agrees well with the observed strain hardening behaviour. The more stable RA progressively transforms during the whole straining process, resulting in higher work hardening rate 
(Jacques et al., 2001b; Furnemont et al., 2002), that, in turn, delays the onset of necking. After necking, ductility may be enhanced due to the contribution of the high volume fraction of film-like RA that is presented in the three steel grades. For this reason, both uniform elongation $\left(\varepsilon_{u}\right)$ and elongation to failure $\left(\varepsilon_{f}\right)$ are very similar for the three samples (Table 4$)$.

\subsubsection{Influence of $P T$}

In order to determine the effect of PT, the target QT was set to $244{ }^{\circ} \mathrm{C}$, followed by isothermal holding during 500 seconds at different PT $\left(300{ }^{\circ} \mathrm{C}\right.$, $350{ }^{\circ} \mathrm{C}$ and $400^{\circ} \mathrm{C}$ ). The RA average size is enlarged with increasing PT $(0.4 \pm 0.1 \mu \mathrm{m}, 0.6 \pm 0.1 \mu \mathrm{m}$ and $0.7 \pm 0.1 \mu \mathrm{m}$, respectively). However, the PT does not have influence on the TM average size (Table 2), as it is determined by the prior austenite grain size (Prawoto et al., 2012; Kaijalainen et al., 2013) and, to some extent, by the QT (section 3.1.1). The RA volume fraction obtained for the sample partitioned at $400{ }^{\circ} \mathrm{C}$ is nearly $4 \%$ higher than for the other two samples (Table 3 ). The effect of PT on microstructure has already been studied. Increasing PT can accelerate the carbon partitioning from martensite to austenite (Santofimia et al., 2008). For example, it was reported in Santofimia et al. (2011b), that for the same QT and Pt, the maximum RA volume fraction is reached at shorter times for higher PTs, i.e. carbon diffusion during partitioning is controlled more effectively by PT rather than Pt. These observations are in good agreement with the obtained results.

Engineering stress - engineering strain curves in Fig. 2b show the effect of PT on mechanical behaviour of the Q\&P processed steel. It is seen that the mechanical behaviour of the samples partitioned at $300{ }^{\circ} \mathrm{C}$ and $350{ }^{\circ} \mathrm{C}\left(\sigma_{U T S}, \varepsilon_{f}\right.$ and $\left.n\right)$ is very similar. For temperatures above $350^{\circ} \mathrm{C}$, ultimate tensile strength and strain hardening exponent decrease with increasing PT, whereas ductility shows an opposite trend (Table 4). Higher volume fraction of RA (Table 3) and larger RA grains (Table 2) in the 244-400-500 sample result in softening of the material and improvement of its ductility, compared to the Q\&P steel grades with the lowest RA content (244-300-500 and 244-350-500 samples).

\subsubsection{Influence of Pt}

The influence of $\mathrm{Pt}$ on microstructure and mechanical properties of a Q\&P steel was also investigated in this work. Samples were partitioned at $400{ }^{\circ} \mathrm{C}$ for 100,500 and 1000 seconds (244-400$100,244-400-500$ and 244-400-1000, respectively) (Table 1). The EBSD phase maps of the three samples partitioned for different times are shown in Figure 1 (g, h and i). Regarding the RA morphology, a mixture of interlath lamellar and blocky type RA can be found in the three conditions. The RA average size is enlarged from $0.5 \mu \mathrm{m}$ to $0.7 \mu \mathrm{m}$, when Pt is raised from 100 to 500 seconds (Table 2); however, it seems to stabilize with further partitioning until 1000 seconds. Apparently, increasing Pt does not have any influence on the TM grain size (Table 2). When Pt is increased from 100 to 500 seconds, the fraction of RA remains almost constant but its carbon content shows an increment from $0.84 \%$ to $1.03 \%$. With further partitioning until 1000 seconds, there is an increment in the RA fraction of up to $\approx 20 \%$, but its carbon content remains approximately constant around 1\% (Table 3).

Figure 2c displays the engineering stress - engineering strain curves from tensile testing of the 244-400-100, 244-400-500 and the 244-400-1000 samples. Mechanical properties are also summarized in Table 4. Ductility seems to be directly related to Pt: increasing elongation to failure $\left(\varepsilon_{f}\right)$ values of $26 \%, 28 \%$ and $29 \%$ are reported for partitioning during 100, 500 and 1000 seconds, respectively (Table 4$)$. The highest $0.2 \%$ proof stress $\left(\sigma_{0.2}\right)$ value is obtained for the 244-400-500 sample, with a value of $821 \mathrm{MPa}$. This could be explained as this sample contains the highest UM fraction (Table 4). It is well known that steels with martensitic microstructure offer an excellent yield strength of about $1000 \mathrm{MPa}$ (Schulz-Beenken, 1997). Regarding ultimate tensile strength $\left(\sigma_{U T S}\right)$, the highest values are found in the sample with smaller RA grain sizes (244-400-100), following the same tendency reported in Section 3.1.2. Finally, the strain hardening behaviour is very similar for the 244-400-500 and the 244-400-1000 samples. The same RA morphology, average grain size and carbon content is found in both samples, so they present a weaker transformation stability compared to the 244-400-100 sample (Sun et al., 2014). This correlates well with the recent study (Xiong et al., 2013) where higher carbon, blocky RA in a Q\&P steel transformed to martensite at the onset of deformation, whereas lower carbon film-like RA remained stable up to $12.5 \%$ strain.

\subsection{Textures after $Q \& P$ treatment}

Figure 3 represents the orientation distribution functions (ODFs) in $\phi_{2}=45^{\circ}, 65^{\circ}$ and $90^{\circ}$ sections of Euler space for samples 244-300-500 (a) and 244-350-500 (b). The textures are calculated only for RA in the material after hot rolling, cold rolling and subsequent Q\&P heat treatment. For the sake of simplicity, two samples with similar RA fractions (Table 3) but different grain sizes (Table 2) are shown. The textures of RA (Fig. 3a and b) are similar and rather weak, with maxima of 3.63 and $2.85 \mathrm{mrd}$ (multiples of a random distribution) occurring for the brass (B) $\{011\}\langle 112\rangle$ component in samples (a) and (b) respectively. Goss (G) $\{110\}\langle 001\rangle$, rotated Goss (RG) $\{110\}\langle 110\rangle, \mathrm{S}\{123\}\langle 634\rangle$ and copper (C) $\{211\}\langle 111\rangle$ also occur in both samples 
(a)

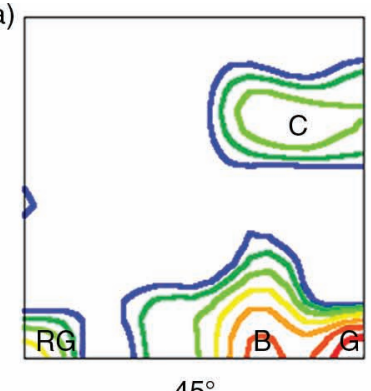

$0.74 \quad 1.00 \quad 1.34$

(b)

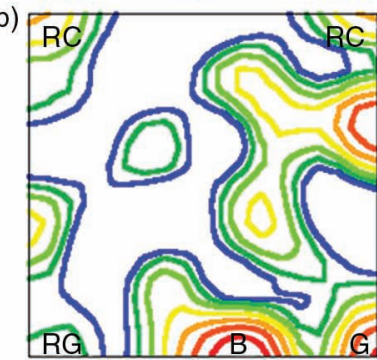

RG. 10

0.81

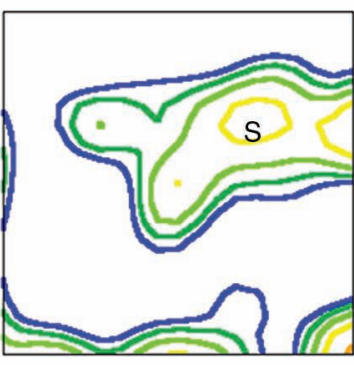

$65^{\circ}$

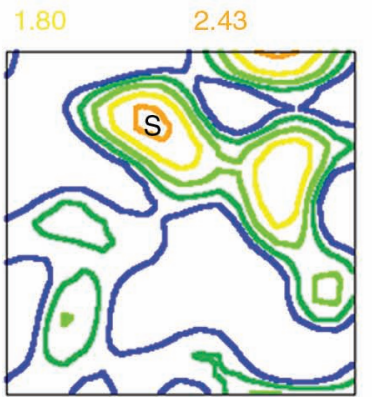

$65^{\circ}$

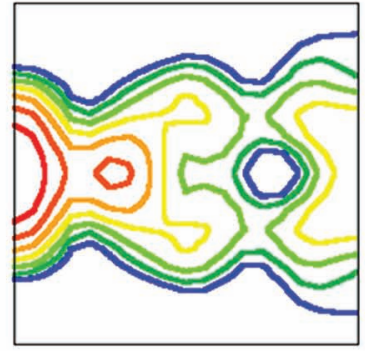

$90^{\circ}$

3.63

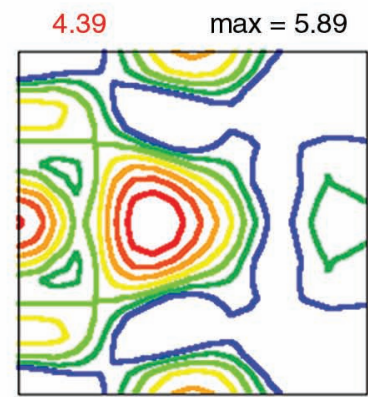

$90^{\circ}$

$2.85 \max =3.53$

FIgURE 3. Orientation distribution functions (ODFs) in $\phi 2=45^{\circ}, 65^{\circ}$ and $90^{\circ}$ sections for austenite in sample $244-300-500$ (a) and sample 244-350-500 (b) $(\mathrm{RC}=$ rotated cube, $\mathrm{C}=$ copper, $\mathrm{RG}=$ rotated goss, $\mathrm{B}=\mathrm{brass}$, and $\mathrm{G}=\mathrm{goss})$.

while the weak rotated cube (RC) $\{001\}\langle 110\rangle$ is only present in the sample 244-350-500. A slight rotation of the $\mathrm{S}\{123\}\langle 634\rangle$ component can be observed for the 244-350-500 sample as well. The major difference in the texture components of austenite between both samples is the presence of RC texture component in the 244-350-500 sample. The transformation potential of this component is between 0.05 and 0.08 with a minimum and maximum of 0.03 and 0.13 respectively (De Knijf et al., 2014b). A high transformation potential indicates low transformation stability related to the texture of the RA grain. Therefore, RA grains having this crystallographic orientation are relatively stable (not taking into account other effects as RA grain size, carbon concentration, morphology, etc...). Hence in this sample, there are more austenite grains which will transform at higher strains resulting in more strain hardening. This can be observed experimentally by the higher $\sigma_{U T S}$ in the stressstrain curves (Fig. 2b). On the other hand, as it can be seen in Fig. 4, the martensite has a crystallographic texture which is frequently observed after double $\alpha-\gamma-\alpha$ transformation of cold deformed bcc phase in AHHSs (De Knijf et al., 2014a). This is because the crystallographic texture has not changed much as a consequence of the Q\&P treatment given to the as-received steel (Petrov et al., 2007; Joo et al., 2012). All texture components observed in the BCC structure originate from deformed austenite with a good agreement with the observed texture of the retained austenite. Note that despite using identical colour scales, there are differences in the strength of the textures (Figs. 3 and 4).

(a)

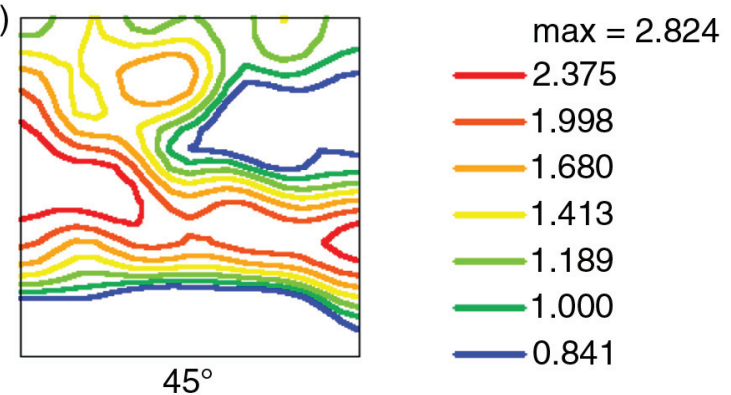

(b)

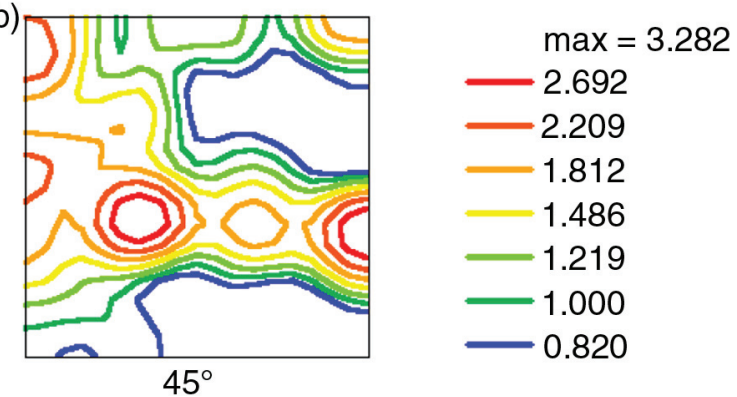

FIGURE 4. Orientation distribution functions (ODFs) in $\phi 2=45^{\circ}$ for: martensite in sample 244-300-500 (a) and sample 244-350-500 (b) 


\subsection{Global and local plastic deformation}

Figure 5 ( $\mathrm{a}, \mathrm{b}$ and $\mathrm{c})$ show the microscale plastic strain $\left(\varepsilon_{y y}\right)$ distributions on the surface of the 244-400-100, 244-400-500 and 244-400-1000 specimens after tensile testing to a global plastic strain of $\sim 10 \%$. The histograms of plastic strain distribution for these samples are also depicted (Fig. 5d). The loading direction during the in situ tensile tensing corresponds to the vertical axis. In all cases, a network-like structure of interconnected bands of localized plastic flow oriented at $45^{\circ}$ to $60^{\circ}$ with respect to the loading axis is clearly seen, whereas a significant fraction of little deformed areas remains present. Note that all plastic deformation maps are represented using identical colour scales, and while there are differences in the strength, all samples show similar patterns of deformation behaviour (Fig. 5a, $\mathrm{b}$ and $\mathrm{c}$ ). Strong partitioning of local plastic strain between different phases is observed. The networklike plastic deformation maps observed in this work are similar to those reported earlier for Q\&P intercritically annealed steels (De Diego-Calderón et al., 2014), Dual Phase (DP) steels (Kapp et al., 2011; Han et al., 2013) and Metal Matrix Composites (MMCs) (Kolednik and Unterweger, 2008). However, the ranges of local plastic strain values vary in all specimens: they are found to be in the range between $5 \%$ and $15.05 \%, 5.7 \%$ and $19.13 \%$ and $5.7 \%$ and $14.62 \%$ for the $244-400-100$, the $244-400-500$ and the 244-400-1000 samples, respectively. From histograms in Fig. 5d, it is also clearly seen that local

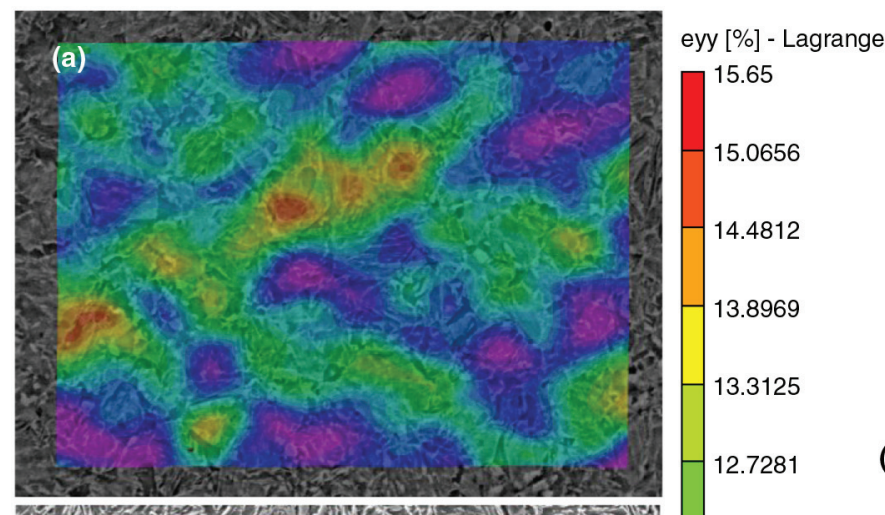

(d)

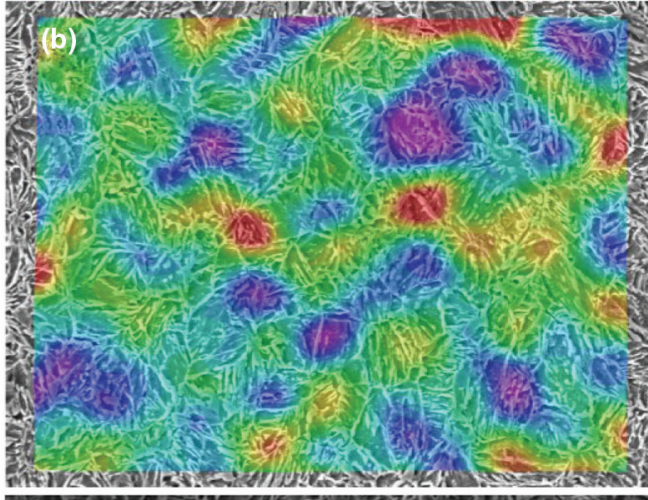

12.1438
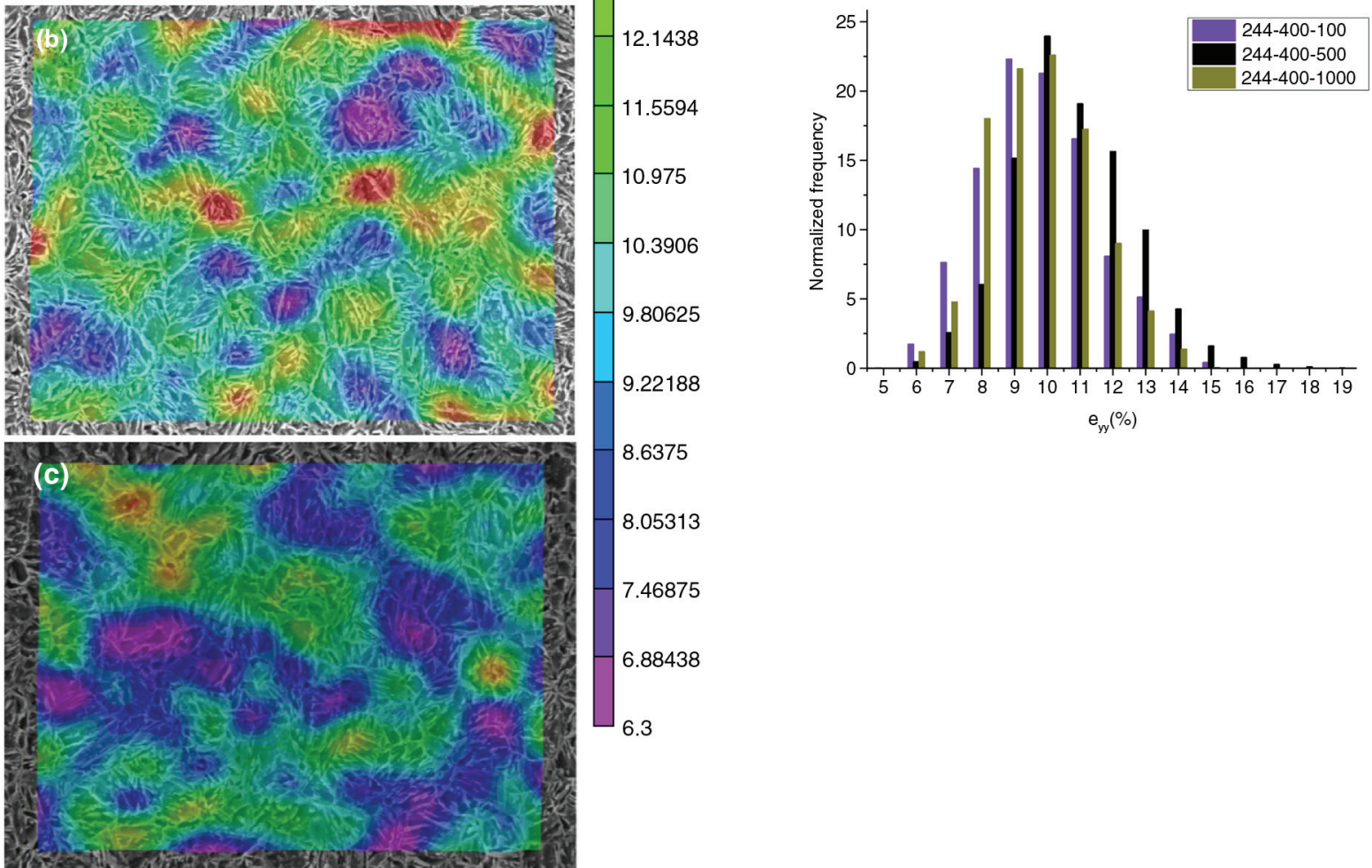

FIGURE 5. Distribution of local plastic strain on surface on: the 244-400-100 sample (a), the 244-400-500 sample (b) and the 244-400-1000 sample (c) after tensile deformation to a global plastic strain of 10\%. Histograms of plastic strain distribution for all samples (d). 
plastic strain tends to have higher values in the 244-400-500 sample. In all cases, the average local plastic strain value is around $10 \%$, corresponding to the imposed global plastic strain.

It was reported in Section 3.1.3 that the global mechanical behaviour $\left(\sigma_{U T S}, \varepsilon_{f}\right.$ and $\left.n\right)$ of the 244-400-500 and the 244-400-1000 samples is very similar. However, significant difference in their local deformation behaviour is clearly seen in Fig. 5 (b and c). It is well known that the local plastic deformation tends to accumulate in the 'soft' microconstituents, whereas 'hard' microconstituents provide less contribution to plastic deformation. In the particular case of these specimens partitioned at $400{ }^{\circ} \mathrm{C}$, global RA fractions determined by XRD and matrix conditions (Tables 3 and 4) are in the same range. However, local EBSD scans yield RA fractions of $7.9 \%, 11 \%$ and $8 \%$ for the $244-400-100$, 244-400-500 and 244-400-1000 samples, respectively. Therefore, the fraction of smallest RA filmlike laths (which cannot be resolved by EBSD) having highest stability, is lowest in the sample partitioned for 500 seconds. Therefore, plastic deformation of the latter sample on the micro-level is quite different compared to that of the 244-400-100 and 244-400-1000 samples (Fig. 5).

\section{CONCLUSIONS}

Steel with a nominal composition of $0.25 \mathrm{C}-1.5 \mathrm{Si}-$ $3 \mathrm{Mn}-0.023 \mathrm{Al}$ (mass \%) was subjected to "Quenching and Partitioning" (Q\&P) treatment with varying Quenching Temperature (QT), Partitioning Temperature (PT) and Partitioning time $(\mathrm{Pt})$. Multi-phase microstructure consisting of different fractions of Tempered Martensite (TM), Untempered Martensite (UM) and Retained Austenite (RA) was obtained. The effect of Q\&P parameters on the microstructure, texture, tensile mechanical properties and plastic deformation at the micro-scale was thoroughly studied. It was shown that:

- $\quad$ The QT does not affect significantly the size and volume fraction of microconstituents, though the morphology of RA strongly depends on QT. Interlath lamellar RA prevails in the microstructure of the samples quenched at $224^{\circ} \mathrm{C}$ and $260{ }^{\circ} \mathrm{C}$ and has high stability against transformation under strain, whereas blocky type RA dominates in the microstructure of the sample quenched at $244{ }^{\circ} \mathrm{C}$. The latter has low stability against transformation under strain which results in higher ultimate tensile strength.

- The PT has a strong effect on size and volume fraction of microconstituents and mechanical properties of the Q\&P steel. The RA average size increases with increasing of the PT, and the highest RA volume fraction is reached after partitioning at $400{ }^{\circ} \mathrm{C}$ due to effective control of carbon diffusion by PT. However, high PT reduces mechanical strength and strain hardening exponent of the material, though its ductility is enhanced.

- The influence of $\mathrm{Pt}$ at $400{ }^{\circ} \mathrm{C}$ on the size and volume fraction of microconstituents is ambiguous. The RA average size tends to grow with increasing Pt up to 500 seconds followed by its saturation, whereas RA volume fraction is not sensitive to $\mathrm{Pt}$ below 500 seconds and increases after partitioning for 1000 seconds. The material shows the highest ultimate tensile strength and strain hardening exponent at the shortest Pt followed by their significant reduction and slight gain in ductility with further increase of the Pt.

- There is no significant influence of Q\&P parameters on the texture of RA. The main observed components include brass $\{011\}\langle 112\rangle$, Goss $\{110\}\langle 001\rangle$, rotated Goss $\{110\}\langle 110\rangle$, and copper $\{211\}\langle 111\rangle$. The weak rotated cube $\{001\}\langle 110\rangle$ is only present in the sample 244-350-500. RA with the latter orientation has higher stability, resulting in the highest ultimate tensile strength for this $\mathrm{Q} \& \mathrm{P}$ condition. The $\mathrm{Q} \& \mathrm{P}$ parameters have no effect on crystallographic texture of martensite. It is similar to the texture frequently observed after double $\alpha-\gamma-\alpha$ transformation of cold deformed bcc phase in AHHSs.

- There is strong partitioning of plastic strain between phases during plastic deformation of the Q\&P steel. Variations of local plastic strain strongly depend on their local microstructure.

\section{ACKNOWLEDGEMENTS}

The authors would like to acknowledge financial support by the Research Fund for Coal and Steel via NewQP project (Grant Agreement $N^{\circ}$ RFSR-CT-2011-00017). DDK acknowledges partial funding by the governmental institute for the Promotion of Innovation by Science and Technology in Flanders, Belgium (IWT). IS acknowledges gratefully the Spanish Ministry of Economy and Competitiveness for financial support through the Ramon y Cajal Fellowship.

\section{REFERENCES}

Ahn, T.H., Oh, C.S., Kim, D.H., Oh, K.H., Bei, H., George, E.P., Han, H.N. (2010). Investigation of strain-induced martensitic transformation in metastable austenite using nanoindentation. Scr. Mater. 63 (5), 540-543. http:// dx.doi.org/10.1016/j.scriptamat.2010.05.024.

Bhadeshia, H.K.D.H. (1999). The bainite transformation: unresolved issues. Mater. Sci. Eng. A 273-275, 58-66. http:// dx.doi.org/10.1016/S0921-5093(99)00289-0.

Blondé, R., Jimenez-Melero, E., Zhao, L., Wright, J.P., Brück, E., Van der Zwaag, S., Van Dijik, N.H. (2014). Mechanical stability of individual austenite grains in TRIP steel studied by synchrotron X-ray diffraction during tensile loading. Mater. Sci. Eng. A 618, 280-287. http://dx.doi. org/10.1016/j.msea.2014.09.008. 
Caballero, F.G., Santofimia, M.J., García-Mateo, C., Chao, J., García de Andrés, C. (2009). Theoretical design and advanced microstructure in super high strength steels. Mat. Design. 30 (6), 2077-2083. http://dx.doi.org/10.1016/j. matdes.2008.08.042.

Caballero, F.G., Allain, S., Cornide, J., Puerta Velásquez, J.D. García-Mateo, C., Miller, M.K. (2013). Design of cold rolled and continuous annealed carbide-free bainitic steels for automotive application. Mat. Design. 49, 667-680. http://dx.doi.org/10.1016/j.matdes.2013.02.046.

Cullity, B.D. (1978). Elements of X-ray diffraction, $2^{\text {nd }}$ Edition, Addison-Wesley, Boston.

De Diego-Calderón, I., Santofimia, M.J., Molina-Aldareguia, J.M., Monclús, M.A., Sabirov, I. (2014). Deformation behavior of a high strength multiphase steel at macroand micro-scales. Mater. Sci. Eng. A 611, 201-211. http:// dx.doi.org/10.1016/j.msea.2014.05.068

De Knijf, D., Petrov, R., Föjer, C., Kestens, L.A. (2014a). Effect of fresh martensite on the stability of retained austenite in quenching and partitioning steel. Mater. Sci. Eng. A 615, 107-115. http://dx.doi.org/10.1016/j.msea.2014.07.054.

De Knijf, D., Nguyen-Minh, T., Petrov, R.H., Kestens, I., Jonas, J.J. (2014b). Orientation dependence of the martensite transformation in a quenched and partitioned steel subjected to uniaxial tension. J. Appl. Cryst. 47 (4), 1261-1266. http://dx.doi.org/10.1107/S1600576714011959.

De Moor, E., Lacroix, S., Clarke, A.J., Penning, J., Speer, J.G. (2008). Effect of retained austenite stabilized via quench and partitioning on the strain hardening of martensitic steels. Metall. Mater. Trans. A 39 (11), 2586-2595. http:// dx.doi.org/10.1007/s11661-008-9609-z.

De Moor, E., Gibbs, P.J., Speer, J.G., Matlock, D.K., Schroth, J.G. (2010). Strategies for Third-Generation Advanced High-Strength Steel Development. AIST Trans. Iron \& Steel Technology 7 (11), 133-144.

De Moor, E., Speer, J.G., Matlock, D.K., Swak, J.H., Lee, S.-B. (2011). Effect of Carbon and Manganese on the Quenching and Partitioning Response of CMnSi Steels. ISIJ Int. 51 (1), 137-144. http://dx.doi.org/10.2355/isijinternational. 51.137 .

Ding, R., Tang, D., Zhao, A. (2014). A novel design to enhance the amount of retained austenite and mechanical properties in low-alloyed steel. Scr. Mater. 88, 21-24. http:// dx.doi.org/10.1016/j.scriptamat.2014.06.014.

Edmonds, D.V., He, K., Rizzo, F.C., De Cooman, B., Matlock, D., Speer, J.G. (2006). Quenching and partitioning martensite-A novel steel heat treatment. Mater. Sci. Eng. A 438-440, 25-34. http://dx.doi.org/10.1016/j.msea.2006.02.133.

Furnemont, Q., Kempf, M., Jacques, P.J., Göken, M., Delannay, F. (2002). On the measurement of the nanohardness of the constitutive phases of TRIP-assisted multiphase steels. Mater. Sci. Eng. A 328 (1-2), 26-32. http://dx.doi.org/ 10.1016/s0921-5093(01)01689-6.

García-Mateo, C. Caballero, F.G., Soumail, T., Kunt, M. Cornide, J., Smanio, V., Elvira, R. (2012). Tensile behaviour of a nanocrystalline bainitic steel containing $3 \mathrm{wt} \%$ silicon. Mater. Sci. Eng. A 549, 185-192. http://dx.doi.org/ 10.1016/j.msea.2012.04.031

Gutiérrez, D., Pérez, Ll., Lara, A., Casellas, D., Prado, J.M. (2013). Evaluación del trabajo esencial de fractura en chapa de un acero de alta resistencia de fase dual. Rev. Metal. 49 (1), 45-54. http://dx.doi.org/10.3989/revmetalm.1213.

Han, Q., Kang, Y., Hodgson, P., Stanford, N. (2013). Quantitative measurement of strain partitioning and slip systems in a dual-phase steel. Scr. Mater. 69 (1), 13-16. http://dx.doi. org/10.1016/j.scriptamat.2013.03.021.

Jacques, P.J., Delannay, F., Ladrière, J. (2001a). On the influence of interactions between phases on the mechanical stability of retained austenite in transformation-induced plasticity multiphase steels. Metall. Mat. Trans. A 32 (11), 2759-2768. http://dx.doi.org/10.1007/s11661-001-1027-4.

Jacques, P., Furnemont, Q., Pardoen, T. Delannay, F. (2001b). On the role of martensitic transformation on damage and cracking resistance in trip-assisted multiphase steels. Acta Mater. 49 (1), 139-152. http://dx.doi.org/10.1016/ s1359-6454(00)00215-9.
Jimenez-Melero, E., van Dijk, N.H., Zhao, L., Sietsma, J., Offerman, S.E., Wright, J.P., van der Zwaag, S. (2007). Characterization of individual retained austenite grains and their stability in low-alloyed TRIP steels. Acta Mater. 55 (20), 6713-6723. http://dx.doi.org/10.1016/j.actamat.2007.08.040.

Joo, M.S, Suh, D.-W., Bae, J.H., Sánchez Mouriño, N., Petrov, R., Kestens, L., Bhadeshia, H.K.D.H. (2012). Experiments to separate the effect of texture on anisotropy of pipeline steel. Mater. Sci. Eng. A 556, 601-606. http://dx.doi. org/10.1016/j.msea.2012.07.033.

Kaijalainen, A.J., Suikkanen, P.P., Limnell, T.J., Karjalainen, L.P., Kömi, J.I., Porter, D.A. (2013). Effect of austenite grain structure on the strength and toughness of direct-quenched martensite. J. Alloy. Compd. 577 (Supplement 1), S642-S648. http://dx.doi.org/10.1016/j.jallcom.2012.03.030.

Kapp, M., Hebesberger, T., Kolednik, O. (2011). A micro-level strain analysis of a high-strength dual-phase steel. Int. J. Mater. Res. 102 (6), 687-691. http://dx.doi.org/10.3139/146.110522.

Kolednik, O., Unterweger, K. (2008). The ductility of metalmatrix composites - Relation to local deformation behavior and damage evolution. Eng. Fract. Mech. 75 (12), 3663-3676. http://dx.doi.org/10.1016/j.engfracmech.2007.08.011.

Paravicini Bagliani, E., Santofimia, M.J., Zhao, L., Sietsma, J., Anelli, E. (2013). Microstructure, tensile and toughness properties after quenching and partitioning treatments of a medium-carbon steel. Mater. Sci. Eng. A 559, 486-495. http://dx.doi.org/10.1016/j.msea.2012.08.130.

Petrov, R., Kestens, L., Wasilkowska, A., Houbaert, Y. (2007). Microstructure and texture of a lightly deformed TRIPassisted steel characterized by means of the EBSD technique. Mater. Sci. Eng. A 447 (1-2), 285-297. http://dx.doi. org/10.1016/j.msea.2006.10.023.

Prawoto, Y. Jasmawati, N., Sumeru, K. (2012). Effect of Prior Austenite Grain Size on the Morphology and Mechanical Properties of Martensite in Medium Carbon Steel. $J$. Mater. Sci. Tech. 28 (5), 461-466. http://dx.doi.org/10.1016/ S1005-0302(12)60083-8.

Rodríguez, E., Suárez, K., Amorer, L., Silva, J. (2014). Caracterización dinámica de los cambios microestructurales en barras de aceros dúplex SAF 2205 utilizando la dimensión de información. Rev. Metal. 50 (1), e007. http://dx.doi. org/10.3989/revmetalm.007.

Santofimia, M.J., Zhao, L., Petrov, R., Sietsma, J. (2008). Characterization of the microstructure obtained by the quenching and partitioning process in a low-carbon steel. Mater. Charact. 59 (12), 1758-1764. http://dx.doi.org/10.1016/j. matchar.2008.04.004.

Santofimia, M.J., Zhao, L., Sietsma, J. (2011a). Overview of Mechanisms Involved During the Quenching and Partitioning Process in Steels. Metall. Mater. Trans. A 42 (12), 3620-3626. http://dx.doi.org/10.1007/s11661-011-0706-z.

Santofimia, M.J., Zhao, L., Petrov, R., Kwakermaak, C., Sloof, W.G., Sietsma, J. (2011b). Microstructural development during the quenching and partitioning process in a newly designed low-carbon steel. Acta Mater. 59 (15), 6059-6068. http://dx.doi.org/10.1016/j.actamat.2011.06.014.

Schneider, C.A., Rasband, W.S., Eliceiri, K. (2012). NIH Image to Image J: 25 years of image analysis. Nat. Method. 9, 671-675. http://dx.doi.org/10.1038/nmeth.2089.

Schulz-Beenken, A.S. (1997). Martensite in Steels : its significance, recent developments and trends. J. Phys. IV France 07 (C5), C5-359-C5-366. http://dx.doi.org/10.1051/jp4:1997557.

Speer, J.G., Matlock, D.K. (2002). Recent developments in lowcarbon sheet steels. JOM 54 (7), 19-24. http://dx.doi.org/ 10.1007/bf02700981

Speer, J., Matlock, D.K., De Cooman, B.C., Schroth, J.G. (2003). Carbon partitioning into austenite after martensite transformation. Acta Mater. 51 (9), 2611-2622. http://dx.doi. org/10.1016/S1359-6454(03)00059-4.

Speer, J.G., Rizzo, F.C., Matlock, D.K., Edmonds, D.V. (2005). The "Quenching and Partitioning Process": Background and Recent Progress. Mater. Res. 8 (4), 417-423. http:// dx.doi.org/10.1590/S1516-14392005000400010.

Speer, J.G., de Moor, E. Clarke, A.J. (2014). Critical assessment: quenching and partitioning. Mater. Sci. Tech. 31 (1), 3-9. http://dx.doi.org/10.1179/1743284714y.0000000628. 
Sun, J.S., Yu, H., Wang, S., Fan, Y. (2014). Study of microstructural evolution, microstructure-mechanical properties correlation and collaborative deformation-transformation behavior of quenching and partitioning (Q\&P) steel. Mater. Sci. Eng. A 596,89-97. http://dx.doi.org/10.1016/j. msea.2013.12.054.

Tan, X., Xu, Y., Yang, X., Wu, D. (2014a). Microstructureproperties relationship in a one-step quenched and partitioned steel. Mater. Sci. Eng. A 589, 101-111. http://dx.doi. org/10.1016/j.msea.2013.09.063.

Tan, X., Xu, Y., Yang, X., Liu, Z., Wu, D. (2014b). Effect of partitioning procedure on microstructure and mechanical properties of a hot-rolled directly quenched and partitioned steel. Mater. Sci. Eng. A 594, 149-160. http://dx.doi. org/10.1016/j.msea.2013.11.064

Tirumalasetty, G.K., van Huis, M.A., Kwakemaak, C., Sietsma, J., Soof, W.G., Zandbergen, H.W. (2012). Deformationinduced austenite grain rotation and transformation in
TRIP-assisted steel. Acta Mater. 60 (3), 1311-1321. http:// dx.doi.org/10.1016/j.actamat.2011.11.026.

van Dijk, N.H., Butt, A.M., Zhao, L., Sietsma, J., Offerman, S.E., Wright, J.P., van der Zwaag, S. (2005). Thermal stability of retained austenite in TRIP steels studied by synchrotron X-ray diffraction during cooling. Acta Mater. 53 (20), 5439-5447. http://dx.doi.org/10.1016/j.actamat.2005. 08.017.

Xie, Z.J., Ren, Y.Q., Zhou, W.H., Yang, J.R., Shang, C.J., Misra, R.D.K. (2014). Stability of retained austenite in multiphase microstructure during austempering and its effect on the ductility of a low carbon steel. Mater. Sci. Eng. A 603, 69-75. http://dx.doi.org/10.1016/j.msea.2014.02.059.

Xiong, X.C., Chen, B., Huang, M.X., Wang, J.F., Wang, L. (2013). The effect of morphology on the stability of retained austenite in a quenched and partitioned steel. Scr. Mater. 68 (5), 321-324. http://dx.doi.org/10.1016/j. scriptamat.2012.11.003 